\title{
NOTES
}

\section{ANTITRUST PROBLEMS RAISED BY PRIVATE REGULATION OF THE AUCTIONING OF LEAF TOBACCO}

Cigarette tobacco is the only major farm crop sold at auction. Its marketing has been subjected to extensive regulation by federal and state agriculture departments, by industry-wide tobacco belt associations, and by warehousemen's boards of trade in each market town.

Federal regulation is designed primarily to aid growers. In so doing, however, it affects the marketing process as well. For example, acreage allotments established by the Secretary of Agriculture to limit production ${ }^{1}$ tend to stabilize prices. Federal inspection, grading and statistical programs, ${ }^{2}$ designed to make the grower better informed, also influence price and market procedure. Pre-harvest loans, intended to finance the farmer until he sells his crop, serve indirectly to fix the minimum price which he will receive for his tobacco. ${ }^{3}$ State stipulation of maximum warehouse charges and licensing of warehouses, ${ }^{4}$ together with statutes which empower public or private agencies to regulate trading, ${ }^{5}$ supplement these federal

1. Acreage allotments are made pursuant to the Agriculture Adjustment Act of 1938, 52 StAT. 31, as amended, 7 U.S.C. $\$ \$ 1281-1376$ (1952). The fact that the yield per acre has almost doubled since the acreage allotment act was passed without a corresponding jump in tobacco produced testifies to the effectiveness of the program. See Agricultural Marketing Service, The Tobacco Situation 52 (1957).

2. Authorized, respectively, by 49 STAT. 731 (1935), 7 U.S.C. $\$ 511$ (1952); 7 C.F.R. pt. 29 (Supp. 1956); 45 STAT. 1079 (1929), 7 U.S.C. \$\$ 501-08 (1952).

3. The Flue-Cured Tobacco Cooperative Stabilization Corporation, a growers' cooperative, borrows money from the Commodity Credit Corporation under contracts which adopt the Secretary of Agriculture's loan values. It then purchases tobacco at auction at the loan value in the absence of a higher bid. See Stroud v. Benson, 155 F. Supp. 482 (E.D.N.C. 1957). Stabilization redries and stores the tobacco, selling it when it can. It has been able to dispose of its stock at prices sufficient to repay its government obligations with interest. The operations of Stabilization are described in Clark \& Browining, Organization of the LooseLEAF Tobacco Auction Market 86-89 (1953).

4. See, e.g., N.C. Gen. Stat. § 106-452 (1953); S.C. Code §69-22 (1952); VA. CODE ANN. §61-128 (1950). The charges of warehousemen in Kentucky and Maryland are not regulated by the state. Auction warehouse charges are set forth for all markets and all groups in Agricultural Marketrng Service, AnNual Report on Tobacco Stamistics 1956, at 41-42 (Stat. Bull. No. 200, 1957) (hereinafter cited as ANNUAL STATISTICs). Charges usually include a small fee per basket, plus a percentage commission on the gross sales price. Normally, the commission is the bulk of the warehouseman's income, running about $\$ 2.50$ per basket as compared with a 25 cent handling fee.

5. MD. Ann. Code art. 48, $\$ 64-76$ (1951) creates a State Tobacco Authority which sets opening dates for Maryland markets; N.C. GEN. STAr. §106-465 (1953) recognizes the local tobacco boards of trade in each market town and gives them power to license buyers and warehousemen and to regulate trading. See text and notes at notes 91-108 infra. 
controls. While governmental regulation is extensive and severely restricts the free play of economic forces in the tobacco market, two important aspects of the auction market process are, in the main, not affected-the manner of bringing together buyers and sellers in the auction warehouses and the day-to-day equating of supply with demand in the market.

Determination of these matters could be left to the undirected operation of the marketing process itself. In fact, however, the warehousemen have undertaken their regulation. Local tobacco boards of trade in each market town schedule and assign the hours during which each warehouseman can sell, and the belt associations determine the opening dates of the markets each season and regulate the daily rate and duration of sales, thus stabilizing the tonnage sold each day.

Although litigants still raise the issue, it is well settled that tobacco auction markets are a part of interstate commerce. ${ }^{6}$ The great proportion of tobacco sold in an auction is grown in the state in which it is marketed, but the sale is followed by a general cross-movement of the tobacco from market to market and from state to state for processing and resale thereafter. $^{7}$ In Currin v. Wallace, ${ }^{8}$ which upheld the validity of the Federal Tobacco Inspection Act of 1935 against the contention that the auctions were not in interstate commerce, the Supreme Court said, "Where goods are purchased in one State for transportation to another, the commerce includes the purchase quite as much as it does the transportation." 9

Since tobacco auctions are a part of interstate commerce, they come within the powers of federal regulation under the commerce clause, and so within the purview of the antitrust laws. ${ }^{10}$ It is the purpose of this Note to consider the antitrust implications of private regulation of tobacco marketing. ${ }^{11}$

6. Rogers v. Douglas Tobacco Bd. of Trade, Inc., 244 F.2d 471 (5th Cir. 1957) ; American Federation of Tobacco Growers, Inc. v. Neal, 183 F.2d 869 (4th Cir. 1950); cf. United States v. Patten, 226 U.S. 525 (1913) (speculators attempting to corner cotton crop in New York market held to be acting in interstate commerce).

7. For example, sixty-five per cent of the tobacco sold in the Wilson, North Carolina, market is taken from there to other states and countries. Wilson Tobacco Bd. of Trade, 1956-57 CCH FTC Complaints, Orders and Stipulations $\llbracket 26,180$ (1956).

8. 306 U.S. 1 (1939).

9. 306 U.S. at 10 .

10. See United States v. South-Eastern Underwriters Ass'n, 322 U.S. 533, 558 (1944), for disctussion of the scope of the antitrust laws.

11. It will be assumed throughout that primary jurisdiction vis $\grave{a}$ vis antitrust problems in this area does not lie in the Department of Agriculture. Several federal statutes granting power to the Secretary of Agriculture with respect to tobacco auctions might be utilized by the Secretary to discourage unreasonable restraints upon trade in the marketing process. Thus, 49 STAT. 731 (1935), 7 U.S.C. $\$ 511$ (1952) authorizes certain inspection activities. These activities are of value to both warehousemen and growers, but the Secretary may exercise discretion in designating the markets to receive this advantage. See also 49 STAT. 734 (1935), 7 U.S.C. $\$ 511 \mathrm{~m}$ (1952) which authorizes the Secretary to cooperate with the local boards. However, none of these acts specifically directs the Secretary to utilize his discretion to prevent unfair methods of competition and restraints upon trade as does the Packers and Stockyards Act of 1921, 42 StAт. 159, as amended, 7 U.S.C. $\$ 181$ 


\section{Validity of Regulation by the Tobacco Belt Associations}

Flue-cured, or bright, tobacco is grown in an area divided into five belts. Burley, on the other hand, is grown in an area which is treated as a unit. Nearly all warehousemen who sell bright belong to a trade association known as the Bright Belt Warehouse Association; burley warehousemen belong to a sister group, the Burley Auction Warehouse Association. ${ }^{12}$ These two belt associations set the dates upon which the warehouses of each belt will open and, through shortening the number of hours a market may be open or declaring a market holiday, stabilize the tonnage of tobacco sold each day.

\section{Setting of Opening Dates}

With the aid of growers and warehousemen, the belt associations attempt to set the opening dates for each belt to coincide with the curing of the bulk of the crop in that area. Bright is first sold in its southernmost belt, Georgia-Florida, about the middle of July; the selling period in the northernmost bright belt ends in November. At that time, burley markets open as scheduled by the burley belt association. ${ }^{13}$ Each belt remains open for approximately seven weeks ${ }^{14}$ with the succeeding belt opening before

(1952); see Frank A. Berigan, 16 Agric. Dec. 503 (1957). Moreover, the Agriculture Department, while expert in its knowledge of the industry, apparently does not have the facilities or expertise to administer a program discouraging restraints of trade. See Hearings Before the Subcommittee of Antitrust and Monopoly of the Senate Judiciary Committee, 85th Cong., 1st Sess. (1957) (concerning S. 1356, which would have withdrawn trade regulation authority in the stockyards industry from the Secretary and returned it to the FTC). It is doubtful that a litigant in an antitrust action could successfully raise the defense that primary jurisdiction in this area lies in the Secretary of Agriculture. See United States v. Swift \& Co., 52 F. Supp. 476 (D. Colo. 1943) (criminal action under the Sherman Act against livestock buyers in which the issue of primary jurisdiction was not raised); United States v. Borden Co., 308 U.S. 188 (1939) (Capper-Volstead Act held not to grant the Secretary of Agriculture exclusive jurisdiction over restraints of trade in folving agricultural producers' cooperatives); REPORT of THE ATTORNEY GENERAL's National Committee To Study the Antitrust Laws 261 (1955) (hereinafter cited as ATTY. GEN. REP.).

It would not be possible for warehousemen's trade associations to claim the broad exemption afforded agricultural producers' cooperatives from the antitrust laws. See United States v. Borden, stupra (exemption does not extend to activities in which other than growers participate).

12. Tobacco grown in Maryland is also used in cigarettes. However, since the FTC proceeding against the Marlboro Tobacco Bd. of Trade, 48 F.T.C. 269 (1951), no trade association has been active in the state. Letter from Professor George Max Beal, Member of the Maryland State Tobacco Authority, to the University of Pennsylvania Law Review, October 24, 1957, on file at the Biddle Law Library. The Authority carries out regulations comparable to those of the belt associations. See MD. ANN. Code art. 48, $\$ 70$ (1951).

13. Maryland tobacco is stored over the winter and sold the following spring. AnNual Statistics at 36-40. Thus, the various types of tobacco are sold in a cycle which occupies much of the year.

14. The short selling season is caused by the large number of market towns where sales take place-about ninety-five for flue-cured and fifty-five for burley. Most tobacco is thereby auctioned within twenty miles of the farm. Hendrickson, in Agricultural Marketing Service, The Auction Marketing of Flue-Cured Tobacco 8, 16 (Market Research Report No. 101, 1955). In the 1946 case, American 
the prior belt has closed. Most tobacco is sold in a belt before the end of the fifth week, however, due to the belief on the part of the growers that buyers will satisfy their needs early, causing prices to fall thereafter in that belt. ${ }^{15}$

Opening sales in each belt on an established date has an advantage for those participants in the auction process who work in each belt seriatim. For example, it is quite common for a warehouseman to operate warehouses in several belts. ${ }^{16}$ Having the warehouses open in each belt at fixed intervals rather than sporadically allows him to schedule his working force so that they can move north as the season progresses.

The major buyers ${ }^{17}$ are also in a position to take advantage of simultaneous opening. At present, one buyer from each of the large domestic and foreign companies joins with the buyers from the others to make up a "set." This set of buyers moves as a unit from sale to sale in the warehouses of a market town and from belt to belt as the season progresses, bidding against smaller local buyers at each sale. ${ }^{18}$ Although a buyer anxious to buy as cheaply as possible would find it in his interest to have the warehouses open sporadically, since he might thereby be able to begin buying in a warehouse before his competitors arrive to bid up the price, the three major domestic buyers, who purchase about thirty-five per cent of the bright and sixty per cent of the burley, ${ }^{19}$ will not bid at auction unless all are present. ${ }^{20}$ This seeming paradox was brought to light in American Tobacco Co. v. United States, ${ }^{21}$ in which these companies were convicted of combining to monopolize the purchase of tobacco. One charge made was that the companies thereby attempted to keep prices so high that no cut-price cigarette manufacturers could survive. ${ }^{22}$ Regardless of the rea-

Tobacco Co. v. United States, 328 U.S. 781 (1946), the Government was able to prove a conspiracy to restrict the number of market towns and thus the number of buyers needed to service them. Some economists favor such restriction. JACKson, The Pricing of Cigarette Tobacco 96 (1955).

15. See Asheville Tobacco Bd. of Trade, Inc., 1956-57 CCH FTC Complaints, Orders aND Stipulations $\llbracket 26,448$ (1957) (appeal to Comm'n pending). Statistics indicate that as the season progresses in each market, prices do have a tendency to fall. Clark \& Browning, op. cit. sipra note 3, at 10. However, this is believed to reflect a contemporary drop in the quality of the tobacco brought to market. Beat \& Summer, Marketing Maryland Tobacco 54 (University of Maryland, Agriculture Experiment Station Bull. No. 451, 1954).

16. This practice is common in both bright and burley warehousing. See letters to the University of Pennsylvania Law Review, filed in the Biddle Law Library, from Albert G. Clay, President, Burley Auction Warehouse Association, November 5, 1957, and F. S. Royster, Managing Director, Bright Belt Warehouse Ass'n, Inc., November 12, 1957.

17. The major domestic buyers are American Tobacco Co., Liggett \& Myers Tobacco Co., and Reynolds Tobacco Co. The major buyers for export are Export Tobacco Co., Imperial Tobacco Co., and Universal Leaf Tobacco Co.

18. See HENDRICKson, op. cit. supra note 14 , at 9.

19. JACKson, op. cit. supra note 14, at 3. Exporters buy a larger percentage of bright than of burley.

20. Id. at 97. See also Hendrickson, supra note 14 , at 14 .

21. 147 F.2d 93, 101 (6th Cir. 1944), aff'd, 328 U.S. 781 (1946).

22. It was admitted by the companies that though they bid on the same tobacco, they intended only to be successful in buying certain types of tobacco 
sons underlying the propensity of the major companies to bid only if all are present, it would appear that the primary purpose of the belt associations in prescribing the dates for sales is to insure that a maximum number of buyers are present at all sales in all belts. To the extent that this causes more buyers to be present at some sales than would otherwise be the case, the result is a higher price for the grower and larger commissions for the warehousemen. The major buyers seem to believe that this system works to their advantage as well. If this be the case, however, it must follow that some other buyers are thereby placed at a disadvantage.

\section{Tonnage Regulation}

The same purpose is evident in the belt associations' programs of tonnage regulation of tobacco sales. Under this program, the burley and bright belt associations attempt to avoid a volume of sales per day larger than the redrying capacity of the major buyers so that no major buyer temporarily drops out of a sale. ${ }^{23}$ Before cigarette tobacco can be put in storage, it must be heat treated, or "redried." In the case of flue-cured tobacco, this must be done within five days after curing, because bright will spoil if it is kept in the moist condition in which it is sold for more than that time. ${ }^{24}$ At certain periods of the year, the markets of two or three belts may be open at the same time. Testimony in Rogers v. Douglas Tobacco $B d$. of Trade ${ }^{25}$ revealed that short-term bottlenecks sometimes resulted at the redrying plants, which would be accompanied by dropping prices and spoiled tobacco as the buyers left the market. ${ }^{26}$

To avoid this result one committee of the association sets the maximum number of baskets of tobacco which may be auctioned per set of buyers per hour. This is usually about four hundred baskets per hour, or one every nine seconds. ${ }^{27}$ Another committee obtains from the United States Department of Agriculture a daily report on the total pounds of tobacco of

within each quality division. The reason given for the extra bidding was to assure that all the competitors paid a fair price. Brief for American Tobacco Co., p. 58, American Tobacco Co. v. United States, 328 U.S. 781 (1946). Recent publications indicate that this is still done. See BEAL \& Summer, op. cit. supra note 15, at 29.

23. See Rogers v. Douglas Tobacco Bd. of Trade, Inc., 244 F.2d 471, 473 n.3 (5th Cir. 1957).

24. Testimony in one case indicates that burley, on the contrary, can keep for thirty days. Findings Proposed by Counsel Supporting the Complaint, pp. 56-78, Asheville Tobacco Bd. of Trade, 1956-57 CCH FTC ConsplannTs, Orders and Stipulations $\llbracket 26,448$ (1957) (appeal to Comm'n pending). Therefore, the possibility that burley might spoil before it is redried is slight.

25. 244 F.2d 471, 473 n.3 (5th Cir. 1957).

26. The main instance of crisis was at the outset of the second world war, when the foreign buyers suddenly left the market. At that time, market conditions depreciated so greatly that the tobacco state governors declared a market holiday. Tonnage regulation was carried out by a trade association of buyers until 1946, the year of the second American Tobacco decision, when the belt associations were formed.

27. In some markets, if the sale in a warehouse falls below a certain speed, the sales supervisor of the local tobacco board of trade will suspend the sale and move the buyers on to the next warehouse in line. 
their type (burley or bright) sold the previous day. This committee also receives reports from the major buyers if their facilities for redrying are temporarily full. If the committee believes, from these two sources, that a reduction in the rate of tobacco sales is necessary to avoid a major buyer's leaving the market, it can do one of two things-either notify the markets to reduce the number of selling hours per day or declare a market holiday, suspending all sales in the belt for one or more days. ${ }^{28}$ Members who sell beyond the prescribed hours are penalized a fixed sum per pound of tobacco so sold. The effect of this regulation is not to reduce the total amount of tobacco that will be sold by a market or belt during a season, but merely to spread the sale over a longer period. ${ }^{29}$

\section{Establishment of Opening Dates and Tonnage Regulation as Restraints of Trade}

Were opening dates for all sales not established by the warehousemen's associations, it seems fair to assume that some growers would be prepared and willing to sell their tobacco earlier than others and that some warehousemen would be desirous of opening their sales earlier than others. Moreover, it is likely that not all warehousemen and growers would suspend selling because of the withdrawal of one of the major buyers were it not for the belt association tonnage regulation program. Some buyers other than the major tobacco companies would probably favor the sporadic opening of markets and the continuation of sales in the absence of the major buyers because of the possibility of lower prices that might result. $^{30}$ It seems clear, therefore, that belt association regulation restrains trade to some degree for the purpose of avoiding the price depression that might occur were one of the major buyers to leave the market. Under the Standard Oil decision, ${ }^{31}$ however, the conclusion that a practice restrains trade is not sufficient to find it illegal within the Sherman Act; further inquiry is necessary to determine whether the practice "unreasonably" restrains trade. ${ }^{32}$

Agreements to fix prices, ${ }^{33}$ divide markets, ${ }^{34}$ limit production ${ }^{35}$ or

28. Federal statistics appear to indicate that the Bright Belt Warehouse Association called only two market holidays during the 1956 selling season, and did not reduce selling time below the $51 / 2$ hour day. Agricultural Marketing Service, Flue-Cured Tobacco Market Review 11 (1957). This is the maximum working day for the industry, because of the severe strain the auction puts on auctioneers and buyers alike.

29. Tobacco is usually stored for two or more years before it is used in the manufacture of cigarettes. Therefore preclusion of purchase on one day results merely in more being purchased at a later time.

30. This possible advantage is limited by stabilization, which guarantees the grower a price about ten per cent below the price that results when all buyers are actively bidding. ANNUAL Statistrcs at 44 . See note 3 supra.

31. Standard Oil Co. v. United States, 221 U.S. 1 (1911).

32. Id. at $60 ; 26$ STAT. 209 (1890), 15 U.S.C. $\$ \$ 1,2$ (1952).

33. E.g., United States v. Trenton Potteries Co., 273 U.S. 392 (1927).

34. See Addystone Pipe and Steel Co. v. United States, 175 U.S. 211 (1899).

35. See Standard Oil Co. v. United States, 221 U.S. 1, 52 (1911); ArT'Y GEN. REP. at 11 . However, in the early case of National Ass'n of Window Glass Mfgrs. v. United States, 263 U.S. 403 (1923), producers in the rapidly contracting 
boycott competitors, ${ }^{36}$ are conclusively presumed to be unreasonable and therefore invalid under section 1 of the Sherman Act. This per se rule is clearly stated in United States $v$. Socony-Vacuum Oil Co., ${ }^{37}$ which involved an attempt by the major oil companies to stabilize the price of gasoline. Independent refiners were shipping gas into areas where there was insufficient demand. Under the NRA, the defendants united in a voluntary program to buy these "distress" shipments at prices slightly above those prevailing, in order to avoid lower prices for their own products. This program continued after the NRA was held invalid. Since mark-ups were standardized by price leadership, setting the price on the spot market effectively set the price on the retail market. ${ }^{38}$ Prices in fact did rise while the program was in operation, but the defendants argued that this was due mainly to increased demand, general betterment of business conditions and an interstate compact which strengthened state proration laws. The Supreme Court, holding the program to be a per se violation, stated:

“. . . [I]n terms of market operations stabilization is but one form of manipulation. . . Under the Sherman Act a combination formed for the purpose and with the effect of . . . stabilizing the price of a commodity in interstate or foreign commerce is illegal per se." 39

Thus Socony involved the establishment of a floor under the market at agreed levels, the purpose and effect of which was to raise prices; there was direct agreement to eliminate a type of price competition. In the case of the tobacco belt regulations, there is no such agreement on price levels or the elimination of a type of price competition, but the purpose and effect of the regulations is nevertheless to stabilize prices by preventing declines that would occur were sales conducted in the absence of major buyers. Direct agreement on prices or the elimination of a type of price competition is sufficient to invoke the per se rule, ${ }^{40}$ but it is less clear that other agreements having an effect on price will suffice. ${ }^{41}$ Both Standard Oil 42 and Trenton Potteries ${ }^{43}$ declared that the enhancement of prices was the ulti-

hand-blown window glass industry who agreed to cut down and stagger their operating hours were held not to have violated the Sherman Act. Their justification was that the remaining supply of skilled workers was too small to permit continuous operation of all the plants. This indicates that production control falls within the per se rule only when its purpose is to affect prices or limit competition.

36. E.g., Fashion Originators' Guild, Inc. v. FTC, 312 U.S. 457 (1941).

37. 310 U.S. 150 (1940).

38. 310 U.S. at 183,193 .

39. 310 U.S. at 223 .

40. This is true even if the agreement places a limit on prices. Kiefer-Stewart Co. v. Joseph E. Seagram \& Sons, Inc., 340 U.S. 211 (1951).

41. Major decisions which have invalidated trade association practices having an effect on price include FTC v. Cement Institute, 333 U.S. 683 (1948); Sugar Institute, Inc. v. United States, 297 U.S. 553 (1936); American Column \& Lumber Co. v. United States, 257 U.S. 377 (1921). Cf. Maple Flooring Mfgrs. Ass'n v. United States, 268 U.S. 563 (1925).

42. Standard Oil Co. v. United States, 221 U.S. 1, 58 (1911).

43. United States v. Trenton Potteries Co., 273 U.S. 392, 397-98 (1927). 
mate evil at which the Sherman Act was directed.44 If that is true, then it would seem to follow that agreement on a course of action calculated to prevent price declines ought to be within the per se rule.

Board of Trade $v$. United States ${ }^{45}$ and United States $v$. Morgan ${ }^{46}$ both cast doubt on the basis of this argument, however. In the Board of Trade case defendants had adopted a rule requiring that all sales of "to arrive" grain made after the closing of the exchange be at the last price registered on the exchange during trading hours. The Court concluded that the rule was merely a regulation of hours of trading rather than a pricefixing agreement, emphasizing that its effect was to increase the number of "to arrive" transactions taking place on the floor of the exchange, and thus to increase competition with respect to these transactions. ${ }^{47}$ It seems probable that the purpose of the regulation was to restrict the ability of the big buyers, who previously had carried on business after exchange closing hours, to make contracts for grain at low, non-competitive prices; the competitive position of small dealers was thereby strengthened.

Although the tobacco program assures the warehouseman a full complement of competing buyers, it operates at the expense rather than for the benefit of the small buyers. Moreover, the price-raising effect in Board of Trade was found to be limited by the fact that the grain was sold in competition with grain sold other than "to arrive," and grain shipped to markets other than Chicago. ${ }^{48}$ This safeguard is not present here, since the great bulk of tobacco is sold under some form of tonnage regulation.

In Morgan, defendant investment underwriters, through syndicates, would stabilize the market price of new issues during the flotation period by buying up offerings below the established price. In rejecting the contention that this constituted price fixing, the court held that the syndicates constituted legitimate joint ventures rather than conspiracies in restraint of trade. ${ }^{49}$ It noted that the stabilization operations were temporary in nature and that stabilization constituted a traditional means of insuring the orderly distribution of securities, beneficial to all parties concerned.50 It is difficult to conceive of the belt associations as being joint ventures, although the belt regulations otherwise bear some resemblance to the practices in Morgan in the sense that they represent temporary measures to insure price stability in the market. The influence of the Morgan dicta on future attempted applications of the per se doctrine is difficult to predict. Many factors appear to have entered into the court's speculation on validity, aside from the joint venture holding. The facts here being considered-the absence of a half-century of satisfactory operation, of express approval of a federal

44. Cf. Justice Brandeis' dissent in American Column \& Lumber Co. v. United States, 257 U.S. 377, 418-19 (1921).

45. 246 U.S. 231 (1918).

46. 118 F. Supp. 621 (S.D.N.Y. 1953).

47. 246 U.S. at $240-41$.

48. Id. at $239-40$.

49. 118 F. Supp. at 684 .

50. Id. at 689 . 
regulatory body, and of competition from other comparable commodities -indicate that Morgan would not be a controlling precedent. Thus, the standards of Socony would apply and the tobacco regulations should be held to be a per se violation of the Sherman Act without an extended analysis of the reasonability of the action taken thereunder.

The effects of the regulation appear to justify such a presumption of unreasonableness. Putting aside the higher commissions which may inure to warehousemen, which cannot justify the restraint imposed, one justification for the regulation might be the higher prices which growers receive. However, it must be assumed that government price support gives the grower all the price protection which the public interest requires. Tonnage regulation permits economic utilization of redrying facilities by spreading the sale of tobacco over a longer period and synchronization of sales in the various belts reduces the number of overhead personnel required to conduct the sales. ${ }^{51}$ But these benefits would seem to be outweighed by the fact that the prices the small buyer and the consumer must pay are probably raised.52 Further, belt association regulation limits the freedom of all in the market to sell or buy when they think conditions are most propitious, and places great power in the hands of people whose allegiance lies mainly with their biggest customers, the major buyers.

If belt regulation were held invalid, either of two results might follow. The states might take over regulation, as has already been done in Maryland ${ }^{53}$ and, partially, in Georgia. ${ }^{54} \mathrm{~A}$ federal statute authorizing interstate compacts ${ }^{55}$ would permit regulation of a scope comparable to that of the belt associations. Such regulation would be more equitably responsive to the needs of all of the market participants, and to the general public as well. Alternatively, redrying facilities might be increased, obviating the need for any type of tonnage regulation at the belt level.

\section{Validity of Regulation by Local Tobacco Boards of Trade}

In each tobacco town there is a local tobacco board of trade composed mainly of warehousemen. ${ }^{58}$ In addition to regulating such matters as the

51. Hendrickson, supra note 14 , at 9 .

52. Since tobacco represents only one-seventh of the final cost of a pack of cigarettes, the effect on the consumer is not nearly as pronounced as on the individual farmer whose tobacco might sell at stabilization price. However, the magnitude of the price effect is not determinative of reasonableness. See United States v. Trenton Potteries Co., 273 U.S. 392, 397-98 (1927).

53. See note 12 supra.

54. Ga. Code Ann. $\S 111-605$ to 111-609 (Supp. 1955). These sections provide that the agriculture department of the state shall suggest opening dates.

55. 49 StAT. 1239-42 (1936), 7 U.S.C. $\$ \$ 515-15 \mathrm{k}$ (1952).

56. In some markets not all the warehousemen are members. See Fayette Tobacco Warehouse Co. v. Lexington Tobacco Bd. of Trade, Inc., 299 S.W.2d 640 (Ky. 1957) (twenty-eight warehouses in Lexington, Kentucky, of which twentyone were members). In North Carolina, boards of trade are allowed by statute to require membership as a condition of operating a warehouse in the market. N.C. Gen. Stat. \$106-465 (1953). This situation is discussed at pp. 584-85 infra. Prior to this enactment it had been held that such a requirement was unlawful. 
rejection and withdrawal of bids ${ }^{57}$ and the prohibition of fraudulent practices, the boards of trade divide the selling time allotted to the market by the belt association among the local warehousemen. This includes establishing the length of time each warehouseman will sell and the sequence in which they will sell. During the selling season there is one auction taking place in the market for each set of buyers sent by the buying companies-as soon as the buyers have bought for the two or three hours allotted by the board to the first warehouse they move on as a unit to the second warehouse. After each warehouse in the market has had its turn, the sale returns to the first warehouse and the sequence is repeated. The time that a warehouseman is allotted directly affects his profits since the overhead of the warehouse, with its short selling season, must be prorated over the receipts from the tobacco he sells, and the more time he is allotted the more tobacco he can sell.

The principal reason, from the standpoint of the growers and warehousemen, for holding sales in succession rather than simultaneously is to insure that as many buyers as possible are present at each sale. Positing that sales are successive, there is a need for some method of revolving the sales among the members which will be orderly and authoritative. One consequence of successive sales is that warehouses do not attract the patronage of tobacco growers purely because of the services they offer; the warehouse which is next in line for sale, and has space and selling time available will get a certain amount of tobacco no matter how poor the service it offers.

The first antitrust problem created by time allocation arises from the fact that each board has an effective monopoly in the market in which it operates. ${ }^{58}$ The major buyers and most of the small ones go only to those warehouses to which the board has allotted selling time. And the growers will take their tobacco mainly to the warehouses these buyers frequent because they feel that prices will generally be higher there. Thus, while it is not impossible to have a sale without the sanction of the local board, the board is able to determine whether a given warehouse will have a successful

Gray v. Central Warehouse Co., 181 N.C. 166, 106 S.E. 657 (1921). In addition to warehousemen, buyers are often members. Growers do not usually belong to the boards unless they belong to a cooperative large enough to bear the initiation fees and dues. CLARK and Browning, op. cit. supra note 3, at 67 . Most boards are dominated by the local warehousemen since the big buyers have become inactive and do not choose to vote.

57. For half an hour after the end of the auction sale, each buyer and each grower have an opportunity to refuse to go through with the sale. See Hendrickson, supra note 14 , at 40 .

58. The court in American Tobacco Growers, Inc. v. Neal, 183 F.2d 869 (4th Cir. 1950) said: "It is argued that defendants do not exert a monopolistic control of the market because plaintiff is at liberty to conduct independent sales in its warehouse notwithstanding their refusal to allot it selling time; but this ignores the realities of the situation. Under the system of market control the defendants have built up, allotment of selling time is a prerequisite of doing business in the market. . . It was just this sort of manipulation, involving the control of markets and the stifling of competition, that the Sherman Act was intended to prevent." Id. at 872 . 
one. ${ }^{59}$ Accordingly, it has been held that a board cannot refuse to allocate a new warehouse selling time, ${ }^{60}$ the exercise of monoply power in concert to exclude competition being a violation of both sections 1 and 2 of the Sherman Act. ${ }^{\text {1 }}$

Free entry itself creates a problem insofar as the rates warehousemen may charge are fixed by the state. ${ }^{62}$ Since the amount of tobacco sold in a market changes little from year to year, new warehouses cause a pressure from the older operators to raise rates to support the increased capacity in the market. The state may adopt one of three solutions-it may refuse to raise rates, thus forcing the less efficient warehouses out of business; it may raise the rates; or it may obviate the problem by itself restricting new entry through requiring a certificate of convenience and necessity. ${ }^{63}$ From

59. See American Tobacco Co. v. United States, 147 F.2d 93, 101 (6th Cir. 1944), aff'd, 328 U.S. 781 (1946); cf. Bright Belt Warehouse Ass'n, Inc. v. Tobacco Planters Warehouse, Inc., 231 N.C. 142, 56 S.E.2d 391 (1949). In the latter case, certain warehousemen in Rocky Mount, North Carolina set up a sale schedule in addition to that set up by the local board. Big buyers were not in attendance but the warehousemen testified that there were no more "turned tags" or rejected bids than in the regular auctions. This may be due to the fact that there was excess tobacco in the area in relation to the selling time allowed to the market, and growers were willing to accept a lower price rather than truck the tobacco to another market.

60. American Tobacco Growers, Inc. v. Neal, 183 F.2d 869 (4th Cir. 1950) (under the Sherman Act); Matter of Mariboro Tobacco Bd. of Trade, 48 F.T.C. 269 (1951) (under $\$ 5(a)$ of the Federal Trade Commission Act of 1914, 38 STAT. 719 , as amended, 15 U.S.C. $\$ 45$ (a) (1952), which forbids unfair methods of competition). In both of these cases warehouses were built a few miles outside of town. The town boards refused to allocate selling time to them, arguing that they should not be required to extend their jurisdiction outside of the town limits. This contention was rejected.

61. See United States v. Griffith, 334 U.S. 100, 107 (1948); Associated Press v. United States, 326 U.S. 1,15 (1945); William Goldman Theatres, Inc. v. Loew's, Inc., 150 F.2d 738 (3d Cir. 1945). Even in the absence of actual preclusion of competition, if monopoly power is coupled with an intent to preserve it, a violation of $\$ 2$ is made out. United States v. Aluminum Co., 148 F.2d 416 (2d Cir. 1945). Such intent can be inferred from actions, the natural consequence of which is to gather or maintain monopoly power. ATT'Y GEN. REP. at 56. Further, where monopoly power has been obtained by combination, as in this case, it has been held that no showing of intent is necessary, since the individuals are not assumed to have combined without an intent to make use of the power they thereby attained. American Tobacco Co. v. United States, 328 U.S. 781, 809 (1946); see also ATr'Y GEN. REP. at 61 .

62. See note 4 supra. Kentucky does not subject warehousemen's charges to public regulation. However, the charges are identical throughout each market town. See AnNual Statistics at 41-42. If these charges are set by agreement in a trade association, or even by two or more warehousemen in combination, they would seem to be clearly illegal under the per se doctrine. United States v. Trenton Potteries Co., 273 U.S. 392 (1927). Where agreement is absent, and the price is set in some way more in the nature of price leadership, the question of legality is not as clear. Compare United States v. United States Steel Corp., 251 U.S. 417 (1920), with American Tobacco Co. v. United States, 328 U.S. 781 (1946). The fact that minimum services and procedures are regulated by the state would make it difficult to prove that equality of price results from anything more than equality of cost. See Pevely Dairy Co. v. United States, 178 F.2d 363 (8th Cir. 1949), cert. denied, 339 U.S. 942 (1950).

63. Most of the states now license warehousemen as a part of their quality control programs, but not to restrict entry. See GA. CoDE ANN. §111 (Supp. 1955); MD. ANN. CODE art. 48, $\$ 73$ (1951). Kentucky licenses the warehouse, rather than the warehouseman. Ky. REv. STAT. $\$ 248.290$ (1953). 
the antitrust standpoint adoption of the first alternative seems preferable to the other two. Of course, under the third alternative, positing that the state may lawfully restrict entry, ${ }^{64}$ the question of entry ceases to be within the purview of the antitrust laws. ${ }^{65}$

Assuming the validity of time allocation in the abstract ${ }^{66}$ and that new entrants are not barred, the method of time allocation adopted by the board becomes crucial and is presently the most litigated issue in the industry. Most tribunals that have dealt with the question have posited that allocation of selling time is valid so long as it does not unreasonably limit competitive merit. ${ }^{67}$ Were there no system of successive sales and allocation of selling time, it would be expected that growers would bring their tobacco to the warehouseman who offered the best service, which includes attempting to get the best price for the tobacco. ${ }^{68}$ A method of allocating selling time should therefore be adopted which departs as little as possible from this norm, i.e., which least discourages service competition. ${ }^{69}$

64. The industry of tobacco auctioning appears to fulfill commerce clause requirements for state regulation of competition. Compare Frost v. Corporate Comm'n, 278 U.S. 515 (1929), with New State Ice Co. v. Liebmann, 285 U.S. 262 (1932).

65. For a discussion of the situation in North Carolina, where the boards are authorized by the state to regulate, see text and notes at notes 91-108 infra.

66. See note 61 supra.

67. See Rogers v. Douglas Tobacco Bd. of Trade, Inc., 244 F.2d 471 (5th Cir. 1957); Asheville Tobacco Bd. of Trade, Inc., 1956-57 CCH FTC ComplaINTS, Orders AND Strpulations $\pi 26,448$ (1957) (appeal to the Comm'n pending); Day v. Asheville Tobacco Bd. of Trade, Inc., 242 N.C. 136, 87 S.E.2d 18 (1955). In only one tribunal has there been presented the issue of whether time allocation is, under any system, an unreasonable restraint of trade. That case held that time allocation is justified if the system used is reasonable. Wilson Tobacco Bd. of Trade, Inc., 1956-57 CCH FTC ComplainTs, ORders aNd StIPULations \$25,808 (1955), aff'd by Comm'n, id. at $\llbracket 26180$ (1956). All other cases have been instituted or instigated by warehousemen who were interested not in striking down the whole allocation program, but in getting more time allotted to themselves. Were the boards' time allocation activities to be struck down it is probable that one of the more primitive time allocation systems might be imposed by the buyers themselves, in view of their preference for travelling in a group. However, such a program might be vulnerable to antitrust proscription as a limited form of boycott.

Some state court decisions do not reach the issue of the validity of time allocation, but resolve these disputes and others relating to board regulations by holding that an association's by-laws are binding on all members. See Cooperative Warehouse, Inc. v. Lumberton Tobacco Bd. of Trade, Inc., 242 N.C. 123, 87 S.E.2d 25 (1955); cf. Fayette Tobacco Warehouse Co. v. Lexington Tobacco Bd. of Trade, Inc., 299 S.W.2d 640 (Ky. 1957). See also Kinston Tobacco Bd. of Trade, Inc. v. Liggett \& Myers Tobacco Co., 235 N.C. 737, 71 S.E.2d 21 (1952), cert. denied, 344 U.S. 866 (1953).

68. An employee of the warehouse bids along with the regular buyers when he feels the price does not reflect the true value of the tobacco. Sometimes this results in the warehouse's buying the tobacco itself. Growers appreciate the high price the warehouseman's bidding brings them. The warehouseman will, in turn, re-sort the tobacco and sell it the next day, making a profit.

69. This is not to say that the antitrust laws necessarily require that the system employed be the most nearly perfect one conceivable. Rather, there is probably an area of reasonableness. An example, perhaps extreme, of this at the state level is the fact that on the same day the North Carolina Supreme Court upheld both the "floor-space" and the "experience" system (discussed infra), against contentions that they unreasonably restrained trade. Day v. Asheville Tobacco Bd. of Trade, Inc., 242 N.C. 136,87 S.E.2d 18 (1955); Cooperative Warehouse, Inc. v. Lumberton 
Systems of time allocation fall into four main categories and variations thereon. ${ }^{70}$ The earliest was known as the "wall-to-wall" or "squirrel-cage" system. Under this system, the warehousemen draw lots to determine who is to have the first sale and who the second, etc. The buyers start at the warehouse which drew first sale and remain there until all the tobacco in the warehouse is sold. Then they go to the warehouse which drew second sale. This method of time allocation is no longer used in the flue-cured markets, but is still used to a certain extent in the burley and Maryland belts. ${ }^{71}$ At first glance, this system would not seem to unduly impair competition, since it allows a warehouseman to sell as much tobacco as he can attract between and during sales. However, his sales are measured by the amount of tobacco he can get in his warehouse at one time. Since he knows that he will get a good percentage of incoming tobacco so long as his sale is going on and he has space to sell it, he will be encouraged to build a larger warehouse than is efficient or is needed on the market. ${ }^{72}$ And if the warehouses are large, there is a possibility that the tobacco in other warehouses will spoil before the buyers get to it. ${ }^{73}$ These problems would be alleviated only by a limit on size which would result in a program analogous to the floor-space system.

The floor-space system gives the warehouseman a proportion of the market's selling time equal to the ratio between his warehouse's (or warehouses') ${ }^{74}$ floor area and the total floor space on the market. ${ }^{75}$ This

Tobacco Bd. of Trade, Inc., 242 N.C. 123, 87 S.E.2d 25 (1955). The federal antitrust statutes would seem to impose a stricter standard. Asheville Tobacco Bd. of Trade, Inc., 1956-57 CCH FTC Complaints, ORDERS AND Stipulations $\pi 26,448$ (1957) (appeal to Comm'n pending), which involved the same parties and the same facts as the Day case. The hearing examiner held that the regulation was an unfair method of competition.

70. A short description of the main methods of allocating selling time is given in Wilson Tobacco Bd. of Trade, Inc., 1956-57 CCH FTC CoMplaINTS, ORDERS AND Stipulations $\llbracket 25,808$ (1955), aff'd by Comm'n, id. at $\llbracket 26,180$ (1956).

71. This system was involved in Fayette Tobacco Warehouse Co. v. Lexington Tobacco Bd. of Trade, Inc., 299 S.W.2d 640 (Ky. 1957), where it was held reasonable under state law.

72. Auction warehousing appears to have become a profitable business since the war. See Hendrickson, supra note 14, at 35; Proposed Findings Submitted by Counsel Supporting the Complaint, p. 24, Asheville Tobacco Bd. of Trade, Inc., 1956-57 CCH FTC Complaints, Orders and Stipulations $\llbracket 26,448$ (1957) (appeal to Comm'n pending). It has been estimated that the average warehouse has a margin of charges over costs of 34.5 per cent. Hendrickson, supra note 14 , at 23. So long as the profits of the warehouseman stand in direct relation with his investment, economics cannot be depended upon to limit warehouses in size.

73. See testimony in Wilson Tobacco Bd. of Trade, Inc., 1956-57 CCH FTC

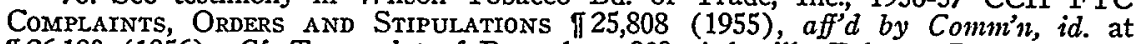
I26,180 (1956). Cf. Transcript of Record, p. 929, Asheville Tobacco Bd. of Trade, Inc., $i d$. I 26,448 (1957) (appeal to Comm'n pending) (testimony by officials of the North Carolina Department of Agriculture that any of the systems will be satisfactory if they are not discriminatorily applied).

74. Under both the unit and the floor-space systems, it is usually possible for an owner to accumulate the time allotted to him for all his warehouses and use it in one warehouse. In this way he can use a smaller work force and use them more efficiently.

75. Floor space in warehouses ranges from 10,000 square feet (one-quarter acre) to 220,000 square feet ( 5 acres). Not all this space can be used in selling tobacco; 
system has the effect of freezing the competitive picture from season to season until there is a physical change in the market's floor space. There is some slight chance for a warehouseman to take advantage of his popularity, created by better service, through the "second sale" program. If one warehouseman has less tobacco attracted to his warehouse than he can sell in his allotted time the sale moves on to the next warehouse, and it will get the benefit of the extra time if it has the tobacco to sell. For example, assume warehouse $A$ is allotted two hours, but sells out its tobacco in an hour and a half. Warehouse $B$, next in line, has been allotted two hours, but has more tobacco than it can sell within that time. Warehouse $B$ can sell for its own two hours, and also use the half-hour unused by $A$.

The extent to which the second sale system allows a warehouseman to increase his sales by offering better service is limited by two factors. First, the market is "blocked" for about half the selling days, i.e., each warehouseman has more tobacco than he can sell in his allotted time. In addition, the basic allotment to each warehouseman remains the same from year to year so that no cumulative growth from second sales is possible. The floor-space system encourages expenditures for huge warehouses beyond efficient size and with no regard to the capacity needed to sell the market's tobacco. ${ }^{76}$ It allows little room for merit to be rewarded, and places an undue premium on capital investment.

Despite these arguments against the floor-space system, it remains the most widely-used method of time allotment in the market today. The North Carolina Supreme Court has upheld the validity of this system under its state restraint of trade statute ${ }^{\mathbf{7 7}}$ but no federal court has as yet tested it.

Under the "unit system," selling time is allocated according to the number of warehouses in the market, each warehouse receiving the same allotment regardless of its floor space. This system also rules out the possibility of competitive growth opportunities from season to season, though the second sales allow some room for competitive activity within a given season. Similarly, the unit system encourages wasteful investment. An operator will expend money for several small warehouses in order to obtain a larger cumulative time allotment.

much is needed for unloading, weighing and storage. Still, all the space is figured in for the warehouseman's allocation. See Cooperative Warehouse, Inc. v. Lumberton Tobacco Bd. of Trade, Inc., 242 N.C. 123, 87 S.E.2d 25 (1955).

76. For example, Lumberton, North Carolina had five times the capacity needed to sell its tobacco. Cooperative Warehouse, Inc. v. Lumberton Tobacco Bd. of Trade, Inc., supra note 75.

77. Cooperative Warehouse, Inc. v. Lumberton Tobacco Bd. of Trade, Inc., 242 N.C. 123, 87 S.E.2d 25 (1955). Many permutations of these systems are possible. For instance, in Rogers v. Douglas Tobacco Bd. of Trade, Inc., 244 F.2d 471, 475 (5th Cir. 1957), the board used a "Unit Floor-Space System." Each warehouse got a unit of selling time for each 55,000 square feet of floor space (or less if the warehouse was smaller than 55,000 square feet). 
A new system of allotment now utilized in a few markets is the "experience" or "historical" system. Each warehouseman gets time in relation to his proportion of the market's sales over the previous one or more years. Thus, if the market sold 100,000 baskets of tobacco, and of these he sold 10,000 , he would get one-tenth of the market's selling time. This system does not result in any freeze of competitive conditions-there is a strong possibility of year-to-year growth or diminution in sales for each warehouseman. As a result several tribunals have found it to be reasonable and valid..$^{78}$ The system cannot start in a vacuum-the initial allotment must be based on sales under one of the other systems mentioned above.79 However, "second sales" on days when the market is not blocked tend to bring the allotments of each competitor closer to what his services merit as each year brings a new computation. ${ }^{80} \mathrm{~A}$ few boards have attempted to restrain this tendency by placing a percentage limit on the growth or decline of selling hours from year to year. ${ }^{81}$ The federal tribunals considering these limitations have properly struck them down as unlawful. 82

Of the four methods of time allocation considered, the floor-space and unit systems are more apt to stifle the free play of competition. ${ }^{83}$ The wall-to-wall system would seem to be a reasonable method so long as the warehouses in the market are not so large as to take over half a day to sell them out. The experience system seems to offer the best opportunity for a warehouseman's profit to be determined by competitive merit, so long as its operation is not artificially limited. ${ }^{84}$

78. Rogers v. Douglas Tobacco Bd. of Trade, Inc., 244 F.2d 471 (5th Cir. 1957); Asheville Tobacco Bd. of Trade, Inc., 1956-57 CCH FTC CoMpraINTs, ORDERs AND Strpulations $\pi 26,448$ (1957); Wilson Tobacco Bd. of Trade, Inc., id. at $\llbracket 26,180$ (1956); Day v. Asheville Tobacco Bd. of Trade, Inc., 242 N.C. 136, 87 S.E.2d 18 (1955).

79. However, basing the initial year's allotment on the past few years' performance under one of the less competitive systems would seem to be preferable to trying to work out an involved formula for each market-based on units, floor space, and perhaps other factors. Such formulae would involve extended debate and probably be not much more, if at all, accurate.

80. The new entrants in the Douglas, Georgia and Asheville, North Carolina markets improve their positions considerably through "second sales." Brief for the Plaintiff, p. 31, Rogers v. Douglas Tobacco Bd. of Trade, Inc., 244 F.2d 471 (5th Cir. 1957) (sold 147 per cent of his allotment the first season); Asheville Tobacco Bd. of Trade, Inc., 1956-57 CCH FTC Complaints, Orders and Stipulations I 26,448 (1957) (appeal to Comm'n pending) (sold over twenty per cent of market's tobacco, although his allotment was only 8.33 per cent). See also Wilson Tobacco Bd. of Trade, id. at $\llbracket 26,180$ (1956) (new entrant was initially allotted 11.17 per cent of selling time; by third year, he had dropped to 6.26 per cent).

81. Ibid.

82. Ibid. Cf. Day v. Asheville Tobacco Bd. of Trade, 242 N.C. 136, 87 S.E.2d 18 (1955) (limitation held reasonable under state restraint of trade statute).

83. Where the market is blocked only a very small percentage of the season, it may be that the second sale program offers reasonable opportunities for competition under these programs.

84. See note 80 supra for cases in which it has been so held. 


\section{Treatment of New Entrants}

The shift from the floor-space system to the experience system in some markets has been of recent origin. Operators were content with the floor-space system until the end of wartime building restrictions gave new competitors the opportunity to build additional facilities. ${ }^{85}$ Since most of the markets used the floor-space system, the new entrants built huge warehouses, regardless of the cover-capacity of the market or the most efficient operating size, in an attempt to acquire a significant share of the selling time. When this happened, many boards attempted to limit the new entrant's competitive advantage by shifting to the experience system, where his floor space would not be such a crucial factor. ${ }^{86}$

Having switched to the experience system, the boards were confronted by a problem which would not exist under any of the other three methods-how to determine the new entrant's initial time allotment. ${ }^{s 7}$ This problem has met with several solutions by individual boards, but it would appear that the best method is to allot time to the new warehouse by the unit method. Thus, if there are nine warehouses in the market before he builds, he would get one-tenth of the available selling time and the other operators would divide the remaining nine-tenths on the basis of the experience system. This method would encourage the new entrant to build a warehouse of the most efficient size, since he will be more

85. The board generally urges the new entrant to buy rather than build. This practice would not seem objectionable under the antitrust laws. In most fields the purchase of a going plant by a new entrant is not as beneficial to competition as the building of a new one, since the latter process results in greater productive capacity in the market. However, this assumes an elastic demand, and demand for tobaccomarketing facilities is relatively inelastic. In addition, the markets now contain four times the capacity needed to sell a season's production. Hendrickson, supra note 14 , at 12 . The probability is that the least popular and efficient operator will be the one to sell, leaving the market in better competitive condition. One problem in this transaction would be how to figure the new entrant's time allocation. If the experience system is in use on the market, it would seem best to allow the new entrant the selling time to which his vendor was entitled. This allotment may be small, if the vendor was comparatively unsuccessful. However, the selling price of the warehouse would be dependent in part upon the vendor's allotment of selling time, and under the experience system the buyer will have adequate opportunity to improve his position.

86. See Rogers v. Douglas Tobacco Bd. of Trade, 244 F.2d 471 (5th Cir. 1957); Asheville Tobacco Bd. of Trade, 1956-57 CCH FTC Complannts, ORders AND Stipulations $\llbracket 26,448$ (1957) (appeal to Comm'n pending); Wilson Tobacco Bd. of Trade, $i d$. at $\Uparrow 26,180$ (1956). It has been said that every adoption of the performance system accompanied the entrance of a new competitor. Proposed Findings Submitted by Counsel Supporting the Complaint, p. 38, Asheville Tobacco Bd. of Trade, supra. Henderson and Sanford, both in North Carolina, adopted the experience system when newcomers entered the market; both have now returned to the unit system.

If the market uses either the floor-space or the unit system, the new entrant can determine his allotment by the manner in which he builds. For example, under the floor-space system, the larger the new warehouse the larger its time allotment. No court seems to have acted to prevent a board from changing its system to the prejudice of an entrant who has already built in reliance on the former system. Nor in view a court act to prevent it.

87. Under the other three systems, the new entrant's time allocation can be determined by the physical aspects of his building. 
interested in his long-term operation than his initial allotment. Using the unit system for the first year discriminates in favor of the new entrant. ${ }^{88}$ However, after the first season, when the growers have had an opportunity to assess his service, he will be on his own. Moreover, his competitors will be stimulated to compete strenuously in order to prevent him from keeping his allotment by default.

Wilson Tobacco Bd. of Trade ${ }^{89}$ approved this method, although there some consideration was also given to the new entrant's investment.90 This modification would seem to be valid under certain conditions, as where the entrant's time allocation under the unit system would allow for the sale of more tobacco than he could possibly accommodate in his warehouse. However, this consideration should be limited to such cases in order to avoid encouraging over-investment.

\section{Effect of State Authorization on Validity of Board Regulation}

In North Carolina, a statute recognizes the existence of the local boards of trade and states that "membership, in good standing, in a local board of trade shall be deemed a reasonable requirement by such

88. Some of the boards have taken this into account by using the "Rocky Mount" system for new entrants. Under this plan, the new entrant gets half of what he would normally have gotten for the first season, and three-quarters for the second. After that, he gets his full allotment. This would seem to be a rather arbitrary device. However, Congress, in enacting the Agriculture Adjustment Act, treated new tobacco farms in much the same way. 52 STAT. 31 (1938), as amended, 7 U.S.C. \$1313(c) (1952). Provision for new entrants in any allotment scheme is always a major problem. See Wall Street Journal, Sept. 17, 1957, p. 12, col. 1 (voluntary cut in petroleum imports); Secretary of Agriculture v. Central Roig Refining Co., 338 U.S. 604, 617 (1950) (allotments for importation of raw sugar).

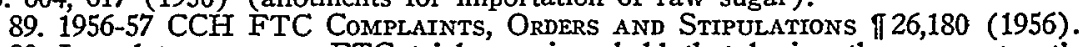

90. In a later case, an FTC trial examiner held that basing the new entrant's time on either (1) average size of old warehouses, (2) average amount of selling time for old warehouses or (3) dividing selling time by total number of warehouses operating, was unreasonable. Asheville Tobacco Bd. of Trade, 1956-57 CCH FTC Complaints, Orders and Stipulations \26,448 (1957) (appeal to Comm'n pending). Because of the Commission's decision in the Wilson case, the reasonableness of the experience method of time allocation was accepted by both parties. This decision would seem to sanction the experience system, but forbid the use of any permutation of either the floor-space or unit system to arrive at the new entrant's time allocation. Either this decision was purposely inconsistent or, if it was the design of the trial examiner to allow the experience system at all, it is much too restrictive. For the only remaining way to determine the new entrant's time would be to allow the new entrant to operate on the wall-to-wall system and allot the remaining time to the other competitors on the experience system. Day had built a huge warehouse. By the time he sold all the tobacco within it (perhaps ten or fifteen selling hours, with four-hour days), there would be little time left for the others. And this advantage would not result wholly through Day's popularity, but rather through the fact that tobacco goes where there is selling time. Thus the system would act to discriminate unduly in favor of the new warehouseman.

It is submitted that the result can be explained in the following way. Day had already entered the market and the remainder of the trial examiner's decision would assure him the selling time he deserved (the 3.5 per cent limitation on growth or decline was struck down). And the market had shifted to the experience system, which would seem to be the best from the standpoint of competition. Testimony at the hearings indicated that other markets, after having shifted to the experience system to combat a new entrant, had reverted to foor space or unit schemes. See note 86 supra. It is probable that the FTC was indicating it would look with disfavor on any shift back to either of those systems on the Asheville market. 
board of trade as a condition to participating in the business of operating a tobacco warehouse or the purchase of tobacco at auction therein." 91 The boards are also empowered to formulate and administer "reasonable rules and regulations for the economical and efficient handling of the sale of leaf tobacco." 92

If the regulations propounded by North Carolina boards, including requirements of membership in the local board as a condition to participating in the market, be considered as taking effect by action of the state in the exercise of its police power, there is authority to suggest that such regulation would not be subject to the antitrust laws. ${ }^{93}$ However, if the statute is interpreted as merely authorizing certain private regulatory activities, such activity remains subject to the antitrust laws. ${ }^{94}$

Two decisions illustrate this difference. Parker $v$. Brozen ${ }^{95}$ involved a California statute which allowed raisin growers to agree to pool their product and regulate production and sale. These plans were then to be approved by a state administrative agency before they became effective. The Supreme Court found the Sherman Act to be inapplicable to the program on the ground that it was not effectuated by contract or conspiracy. ${ }^{96}$ It was dependent on the approval of the state agency, and the state was subject only to the less restrictive limitations of the commerce clause. ${ }^{97}$ Schwegmann Bros. v. Calvert Distillers $C_{0}{ }^{98}$ involved the enforceability against a non-signer of a resale price-fixing contract entered into pursuant to a state fair trade law. The Supreme Court held that this contract was subject to the Sherman Act, despite the fact that the price regulation was pursuant to authorization by the state. ${ }^{99}$

91. N.C. Gen. STAT. §106-465 (1952). In the absence of a statute, the board cannot require membership as a condition to access to the markets. Gray v. Central Warehouse Co., 181 N.C. 166, 106 S.E. 657 (1921).

92. Ibid. None of the other tobacco states have seen fit to enact similar statutes.

93. E.g., Parker v. Brown, 317 U.S. 341, 350-52 (1943) ; Lowenstein v. Evans, 69 Fed. 908 (C.C.D.S.C. 1895).

94. E.g., Schwegmann Bros. v. Calvert Distillers Corp., 341 U.S. 384 (1951); Northern Securities Co. v. United States, 193 U.S. 197 (1904).

95. 317 U.S. 341 (1943).

96. 317 U.S. at $350-52$.

97. In general, state regulation under the police power which affects commerce does not conflict with the commerce clause if three requirements are met: one, the regulation is designed to solve a local problem which, because of the diversity of local conditions, does not demand a uniform solution by Congress, Cooley v. Board of Port Wardens, 53 U.S. (12 How.) 299 (1851); two, the regulation does not discriminate against commerce, Morgan v. Virginia, 328 U.S. 373 (1946); and three, the local benefit outweighs any harm to commerce, Toomer v. Witsell, 334 U.S. 385 (1948). Regulation of the sale of tobacco at auction has been held to satisfy the first two of these requirements. Townsend v. Yeomans, 301 U.S. 441, 451-52 (1937).

98. 341 U.S. 384 (1951).

99. 341 U.S. at 386 . Note also that state regulated industries have been held to be subject to the Sherman Act, even though they may be acting within state authorization. United States v. South-Eastern Underwriters Ass'n, 322 U.S. 533, 561 (1944); see also the McCarran-Ferguson Act of 1945, 59 STAT. 34, as amended, 15 U.S.C. $\$ 1012$ (1952), which was enacted to free certain insurance practices from the operations of the Sherman Act. 
The limitations imposed on state activity by the commerce clause differ from those imposed by the Sherman Act on private activity. In both cases the harm to interstate commerce must be analyzed and evaluated. However, the Sherman Act strikes down some regulations which would be lawful under the commerce clause were they state-imposed. ${ }^{100}$ The justification for this difference in treatment seems to lie in the requirements of a federal system. State governments have the authority to regulate matters of local concern affecting the health, safety and welfare of their people. The legitimate exercise of this power in furtherance of such interests must be accommodated by the federal government in the exercise of its power to regulate interstate commerce where the two are in conflict. The decisions of individuals, on the other hand, are generally directed to the promotion of their own interests and, therefore, the protection of commerce permits greater restriction of their behavior. While private regulation may in fact achieve a desirable public result, the risk that it will not justifies a closer control than would be required of a public body. ${ }^{101}$

Both the Parker and Schwegmann cases involved regulation by individuals normally proscribed by the Sherman Act-in the former, restriction of production, and in the latter, retail price fixing. It would appear that the principal distinction between the two cases is the closer identification of the regulations with the local public interest which was achieved by the requirement of subsequent state approval of the raisin producers' regulations, as was required by the statute in Parker. In Schregegmann, the state ended its contact with the regulation with its legislative grant of power to the businessman; no agency of the state was required to make a finding that the price set by the individual was in keeping with the public interest.

The regulations of the tobacco warehousemen would appear to be more analogous to those in Schwegmann than to those in Parker v. Brozen. The North Carolina statute requires that the regulations be directed to orderly and efficient marketing, which gives the state courts an opportunity to test them against the public interest when they are challenged, ${ }^{102}$

100. The state can create a monopoly when it is acting within its police powers. Frost v. Corporation Comm'n, 278 U.S. 515 (1929); Olsen v. Smith, 195 U.S. 332 (1904); cf. Okefenokee Rural Elec. Membership Corp. v. Florida Power \& Light Co., 214 F.2d 413 (5th Cir. 1954); Suni-Citrus Products Co. v. Vincent, 72 F. Supp. 740 (S.D. Fla. 1947).

101. See Carter v. Carter Coal Co., 298 U.S. 238, 311 (1936) ; Cox v. Kinston, 217 N.C. 391, 395, 8 S.E.2d 252, 256 (1940) ; Note, 67 HARv. L. Rev. 1398 (1954); cf. Opp Cotton Mills v. Administrator, 312 U.S. 126 (1941).

102. Of course, if the regulations are beyond the authority given by the state legislature, there is no color of state law shielding them, thereby clearly subjecting them to Sherman Act standards. In this instance, the statute states that it is not meant to authorize restraints of trade by the boards. Still, the North Carolina Supreme Court has upheld time allocations by the boards as being within the power delegated by the legislature and a valid delegation under the state constitution. Cooperative Warehouse, Inc. v. Lumberton Tobacco Bd. of Trade, Inc., 242 N.C. 123, 87 S.E.2d 25 (1955); Day v. Asheville Tobacco Bd. of Trade, 242 N.C. 136, 87 S.E.2d 18 (1955). Cf. Fink v. Cole, 302 N.Y. 216, 97 N.E.2d 873 (1951) (delegation to 
whereas no standard was provided in Schregegmann. But, the state has not provided for subsequent approval by an administrative agency, such as was the case in Parker, or for some form of administrative review. Judicial review cannot compare as a safeguard of the public interest with the Parker procedure. A regulation must be challenged rather than being automatically subjected to approval. The adjudicatory process is much slower and more costly. And all the persons whose interests are involved might not be adequately represented in such an adjudication. There is thus less assurance than in Parker that the warehousemen will enact regulations consistent with the public interest. ${ }^{103}$ Since the danger is that these individuals will restrain trade for private gain, the regulations pursuant to this statute should be treated as acts of individuals authorized to engage in regulatory activity and not as acts of the state itself. ${ }^{104}$ Thus, they should be evaluated by the standards of the antitrust laws, as are the regulations of boards in the other tobacco states. ${ }^{105}$

The danger to the public interest seems particularly great with respect to the authority conferred on the boards to require membership as a condition of participating in the market. Such power might easily

private club to license jockeys struck down) ; State v. Harris, 216 N.C. 746, 6 S.E.2d 854 (1940) (delegation to cleaners to make regulations struck down); Union Trust Co. v. Simmons, 116 Utah 422, 211 P.2d 190 (1949) (statute which required new bank to get approval from other banks in locality struck down); see also Comment, 31 N.C.L. REv. 308 (1953).

103. Calling this state action would enable a state legislation to authorize individuals to engage in limited competition plans in any industry "appropriate for state action" and thus take the individuals outside the limitations of the Sherman Act. Notably, the industrialists within the state have a much greater opportunity to secure state legislation in their behalf than do consumers outside the state to prevent it. It would therefore seem that in order to prevent an avoidance of Sherman Act standards by lobbying, such programs should be scrutinized as independent of the state authorization. See Pennsylvania Water \& Power Co. v. FPC, 193 F.2d 230 (D.C. Cir. 1951), aff'd, 343 U.S. 414 (1952); Note, 102 U. PA. L. Rev. 368 (1954); cf. Note, 106 U. PA. I. Rev. 69 (1957) (suggests that such lobbying might itself be a violation of the Sherman Act).

104. The North Carolina Supreme Court has twice passed upon time allocation programs of the boards and found them within the public interest. Cooperative Warehouse, Inc. v. Lumberton Tobacco Bd. of Trade, Inc., 242 N.C. 123, 87 S.E.2d 25 (1955); Day v. Ashville Tobacco Bd. of Trade, 242 N.C. 136, 87 S.E.2d 18 (1955). It might be argued that these programs, since they have been found to be within the public interest of the state, should be subject only to the commerce clause. However, this would make the legal result depend upon whether suit on a particular program was brought first in a state or a federal court. To avoid inconsistency, it would appear desirable to test all regulations by the Sherman Act.

105. This issue has never been authoritatively passed upon. Both of the suits brought against boards of trade in the federal courts have involved boards from states other than North Carolina. Rogers v. Douglas Tobacco Bd. of Trade, 244 F.2d 471 (5th Cir. 1957) (Georgia); American Federation of Tobacco Growers, Inc. v. Neal, 183 F.2d 869 (4th Cir. 1950) (Virginia). Two of the FTC cases have involved North Carolina boards. Asheville Tobacco Bd. of Trade, 1956-57 CCH FTC ComplaInTs, ORDERS AND STIPULATIONS $\llbracket 26,448$ (1957); Wilson Tobacco Bd. of Trade, id. at $\pi 26,180$ (1956). In the former case, the Attorney General of North Carolina filed a brief amicus curiae, arguing that the antitrust acts do not apply to the regulation, since it involves state action. The trial examiner's opinion assumed that the Federal Trade Commission Act does apply to the North Carolina boards. Thus, no tribunal has ever discussed the issue. 
be utilized to limit competition. Nor is this possibility of harm compensated by any local benefit:106 membership of all warehousemen is not necessary to secure compliance with the board's other regulations since by the terms of the statute itself, all in the market are directed to adhere to the reasonable rules of the board. ${ }^{107}$ The potential harm to commerce would therefore seem to forbid that buyers or warehousemen be compelled to seek membership in order to participate in the market. ${ }^{108}$

M. E.

106. It might be argued that the requirement of membership, along with the membership fees charged by the boards, serves to provide a fund to support their activities as a regulatory group. However, it would appear that a small levy on the sales would achieve the same result without the restraint on commerce obvious here.

107. See Kinston Tobacco Bd. of Trade, Inc. v. Liggett \& Myers Tobacco Co., 235 N.C. 737, 71 S.E.2d 21 (1952), cert. denied, 344 U.S. 866 (1953). The duty of buyers to obey the regulations of the board was tested against the enabling statute, without consideration of the fact that the buyers were members of the board.

108. It has been held that requiring an interstate buyer to have a state license violated the commerce clause. Shafer v. Farmers Grain Co., 268 U.S. 189 (1925). However, that case involved an additional burden on commerce. Maryland requires licensing of tobacco dealers and manufacturers, who are also the buyers. Mo. Ann. Code art. 48, §73 (1951). 